\title{
BENZIMIDAZOLE RIBONUCLEOSIDES: OBSERVATION OF AN UNEXPECTED NITRATION WHEN PERFORMING NON-AQUEOUS DIAZOTIZATIONS WITH t-BUTYL NITRITE 1
}

\author{
Rodrigo V. Devivar, John C. Drach, and Leroy B. Townsend* \\ Department of Medicinal Chemistry, College of Pharmacy, Department of Biologic and Materials Sciences, \\ School of Dentistry, and the Department of Chemistry, College of Literature, Science and Arts, \\ The University of Michigan, Ann Arbor, MI 48109-1065
}

(Received 9 July 1992)

\begin{abstract}
Mild, non-acidic conditions used in the non-aqueous diazotization of a 2 -aminobenzimidazole nucleoside with $t$-butyl nitrite gave an unexpected 4-nitrobenzimidazol-2-one nucleoside which was not formed when primary alkyl nitrites were used. The isolated compounds were evaluated for activity against herpesviruses and for cytotoxicity against human foreskin fibroblast cells.
\end{abstract}

Benzimidazoles have demonstrated widespread biological activity ranging from antifilarial ${ }^{2}$ to antiviral. Since the initial report ${ }^{3}$ of activity for halogenated benzimidazole ribonucleosides against certain RNA viruses, considerable interest has been generated among analogs of 5,6-dichloro-1-( $\beta$-D-ribofuranosyl)benzimidazole (DRB). Recently, we have found that polyhalogenated benzimidazole ribonucleosides are potent and selective inhibitors of human cytomegalovirus (HCMV) replication. In an effort to establish a structure-activity relationship in this specific area, we have been preparing and evaluating new benzimidazole ribonucleosides. It was during the preparation of these compounds that we encountered an interesting observation pertaining to non-aqueous diazotization.

Non-aqueous diazotization employs the known ability of alkyl nitrites to produce aryl radicals from arylamines 4 the ensuing aryl radical can then abstract an atom from a suitable donor such as the solvent. Although an early use of non-aqueous diazotization using THF as the solvent involved the deamination of

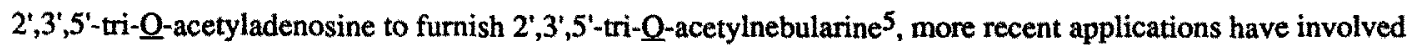
the synthesis of various halogenated nucleosides 6 . The deamination-halogenation of purine nucleosides with alkyl nitrites in halogenated solvents has been reported to occur at the 6-position ${ }^{7}$ and the 2-position ${ }^{8,9}$ to provide various halogenated purine nucleosides. Although the synthesis of several 2-halogenated benzimidazole nucleosides has been reported, ${ }^{10-12}$ the non-aqueous diazotization of benzimidazole nucleosides to afford the corresponding 2 -halogenated nucleosides has not. We now wish to report on the unexpected results from a nonaqueous diazotization of a 2-amino-5,6-disubstituted benzimidazole riboside when using a tertiary alkyl nitrite and the antiviral evaluation of the isolated compounds.

Treatment of 2-amino-5,6-dichloro-1-(2,3,5-tri-Q-acetyl- $\beta$-D-ribofuranosyl)benzimidazole ${ }^{13}(1)$ with 10 equiv of $t$-butyl nitrite in $\mathrm{CH}_{2} \mathrm{I}_{2}$ under anhydrous conditions for $24 \mathrm{~h}$ at $110^{\circ} \mathrm{C}$ gave (after solvent removal via a Kugelrohr apparatus and column chromatography) a bright-yellow product. $\mathrm{A}$ mass spectrum (FAB ${ }^{+}$) of the product identified a molecular ion at $m / z 506$ instead of the expected $m / z 571$ for 5,6-dichloro-2-iodo-1-(2,3,5-triQ-acetyl- $\beta$-D-ribofuranosyl)benzimidazole (3). The structure of this unexpected product ( $\mathrm{m} / \mathrm{z}$ 506) was

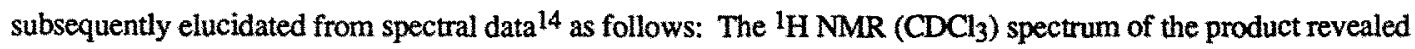
an exchangeable proton at $\delta 10.05$ (one proton, $\mathrm{D}_{2} \mathrm{O}$ exchangeable) and only one peak (one proton) in the aromatic region at $\delta 7.56$. The ${ }^{13} \mathrm{C} N \mathrm{NMR}$ spectrum revealed the presence of a urea-like carbon at $\delta 152.70$. These data indicatcd that changes or substitutions had occurred on both the benzo and imidazo moieties of the benzimidazole 


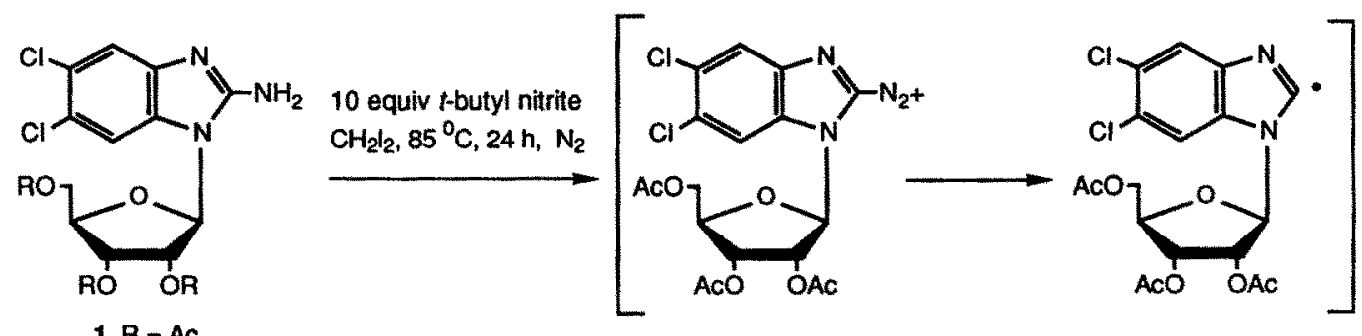

$1 R=A C$

$2 R=H$

10 equiv $t$-butyl nitrite

$\mathrm{CH}_{2} \mathrm{l}_{2}, 110^{\circ} \mathrm{C}, 24 \mathrm{~h}, \mathrm{~N}_{2}$
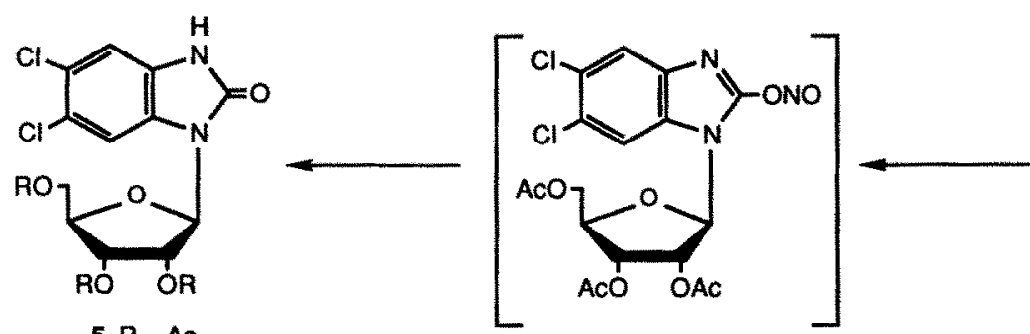<smiles>Clc1cc2nc(I)[nH]c2cc1Cl</smiles>

$\mathrm{RO}_{7}$

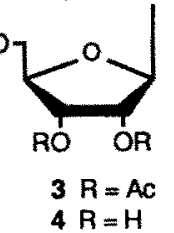

$5 R=A C$
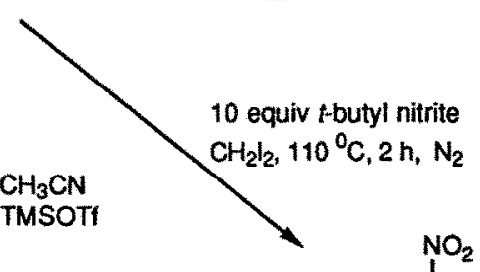

1. $\mathrm{BSA}, \mathrm{CH}_{3} \mathrm{CN}$

2. TAR, TMSOTI<smiles>O=c1[nH]c2cc(Cl)c(Cl)cc2[nH]1</smiles>

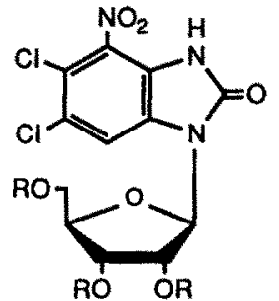

$8 \mathrm{R}=\mathrm{AC}$

$9 \mathrm{R}=\mathrm{H}$
1. $\mathrm{NH}_{3} / \mathrm{MeOH}$

2. $\mathrm{PlO}_{2} / \mathrm{H}_{2}$

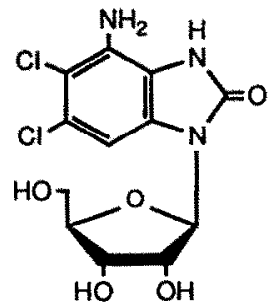

10 
ring and established that the product was not the expected compound 3. This led us to the conclusion that the unexpected product was a trisubstituted benzimidazol-2-one nucleoside with what we presumed to be a $\mathrm{NO}_{2}$ group residing on the benzene moiety (compound 8, IR (KBr): $1542 \mathrm{~cm}^{-1}$ ).

The site of functionalization on the benzene portion of 8 was determined by an NOE experiment. Irradiation of the lone aromatic proton ( 87.56 ) gave a $6.7 \%$ NOE enhancement of $\mathrm{H}-2$ ' and a $6.6 \%$ NOE enhancement of $\mathrm{H}-1$. These observations indicated that 8 was indeed a 4 -substituted benzimidazol-2-one. The $\mathrm{NO}_{2}$ group could be bonded through either a nitrogen or an oxygen atom and required further structural confirmation. The possibility of $O$-nitrosation was excluded by effecting a reduction of 9 to 10 which provided an amino substituent, and not a hydroxyl group. A quantitative removal of the acetyl protecting groups from 8 was followed by a catalytic hydrogenation under $\mathrm{H}_{2}$ in the presence of $\mathrm{PtO}_{2}$ in ethanol to give 10 in $92 \%$ yield 15 .

In an effort to elucidate the mechanism of this reaction by isolating some of the intermediates, the temperature was lowered to $85^{\circ} \mathrm{C}$. Within $5 \mathrm{~min}$, the starting benzimidazole 1 had been consumed and a new product had been formed. After $20 \mathrm{~min}$, three products could be detected by TLC. At $3 \mathrm{~h}$, with all three products still prevalent, the solvent was removed and the three compounds were isolated by column chromatography. Spectral analysis ${ }^{14,}, 16,17$ of these compounds allowed us to assign their structures as 3,5 , and 8 . By monitoring the progress of the reaction by TLC, we were able to determine that the reaction proceeded sequentially with the initial formation of 3 , then 5 , and finally 8 . Clearly, the expected 2-iodobenzimidazole nucleoside 3 had formed rather quickly, and the continued exposure of this compound to the reaction conditions led to the displacement of the 2-iodo group and ultimately the benzimidazol-2-one nucleoside 5 . Compound 5 was then nitrated in situ giving the novel 4-nitrobenzimidazol-2-one nucleoside 8 .

An alternative synthesis ${ }^{17}$ of compound 5 by ribosylation of the known 5,6-dichlorobenzimidazol-2-one ${ }^{18}$ (7) helped to establish its role as an intermediate. When 5 was treated with 10 equiv of $t$-butyl nitrite in diiodomethane at $110^{\circ} \mathrm{C}$, a complete conversion to compound 8 was observed within $2 \mathrm{~h}$ without the detection of any other intermediates. Compound 8 was isolated from this reaction in $86 \%$ yield after recrystallization.

The final diazotization product obtained with $t$-butyl nitrite was in sharp contrast to the results obtained when a primary alkyl nitrite was used. The treatment of compound 1 with either amyl or isoamyl nitrite under

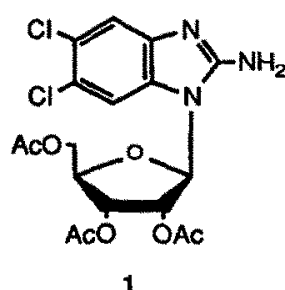

1

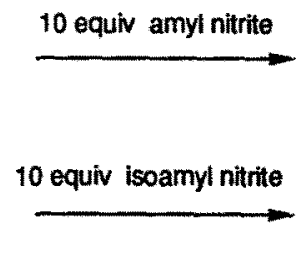

0 equiv isoamyl nitrite

the same reaction conditions gave only the expected 5,6-dichloro-2-iodo-1-(2,3,5-tri-Q-acetyl- $\mathrm{\beta}$-D-

ribofuranosyl)benzimidazole (3) in $55 \%$ and $63 \%$ yields, respectively. The reaction product composition did not change even after $12 \mathrm{~h}$. We also noted that treatment of 5 with 10 equiv of isoamyl nitrite at $110^{\circ} \mathrm{C}$ in diiodomethane did not lead to the formation of any products even after $24 \mathrm{~h}$. While it is widely accepted that the 
pyrolysis and photolysis of $t$-butyl nitrite results in the formation of $t$-butoxyl radical and nitric oxide, the in situ nitration of compound 8 from 5 suggests that a different type of thermal decomposition is occurring. We can propose that the tertiary alkyl nitrite undergoes thermal decomposition giving rise to products which are more stable than their counterparts when primary alkyl nitrites are used. These thermal decomposition products are responsible for the observed displacement of the 2-iodo group of compound 3 and the in situ nitration of compound 5.

The protected nucleosides $1,3,5$, and 8 were treated for $16 \mathrm{~h}$ with a methanolic ammonia solution (prepared by saturating methanol with ammonia gas at $0^{\circ} \mathrm{C}$ ) to achieve a removal of the acetyl protecting groups and give the unprotected nucleosides $2,4,6$, and 9, respectively. The unprotected nucleosides were evaluated for their ability to inhibit HCMV replication using plaque and yield reduction assays 19,20 and for cytotoxicity against uninfected human foreskin fibroblasts (HFF) cells. These data were compared to results we have obtained with the 2-unsubstituted 5,6-dichloro-1-( $\beta$-D-ribofuranosyl)benzimidazole (DRB) and the clinically approved anti-HCMV agent DHPG. Of the compounds tested, 2 was somewhat active against HCMV but also cytotoxic in HFF cells, indicating that activity against the virus was a consequence of cell toxicity. Compound 4 was active against HCMV in both the plaque reduction and yield reduction assays and demonstrated some activity against HSV-1.

These data suggest that the type of substituents on the 5,6-dichloro-1-( $\beta$-D-ribofuranosyl)benzimidazole moiety is critical for optimal antiviral activity. Those compounds having a benzimidazol-2-one functionality were devoid of any activity. When compared to the 2-unsubstituted compound (DRB), we found that the introduction of an amino group at the 2-position did not alter the anti-HCMV activity or the cytotoxicity. However, introduction of an iodine atom at the 2-position improved the selectivity by decreasing the cytotoxiciry observed on uninfected HFF cells.

ANTTVIRAL EVALUATION

\begin{tabular}{ccccc}
\hline \multirow{2}{*}{ Compound } & HCMV Plaque & HCMV Yielda & HSV -1 & HFFb \\
\hline 2 & 40 & - & 50 & 32 \\
$4 \mathrm{c}$ & 30 & 26 & 21 & 127 \\
6 & $>100$ & - & $>100$ & 100 \\
9 & $>100$ & - & $>100$ & 100 \\
10 & $>100$ & - & $>100$ & $>100$ \\
DRB $19, \mathrm{c}$ & 42 & 19 & 30 & 24 \\
DHPG & $7.9^{\mathrm{d}}$ & $2.0^{\mathrm{c}}$ & $3.5^{\mathrm{c}}$ & $>100^{\mathrm{d}}$ \\
\hline
\end{tabular}

a90\% inhibitory concentration. bVisual cytotoxicity in HFF cells scored at 30 -fold magnification at time of HCMV plaque enumeration. ${ }^{\mathrm{c}}$ Results are the average of 3 or more experiments. dResults are the average of 50 or more experiments. 
While gaining insight into the structural modifications that may be made on benzimidazole nucleosides in order to optimize activity, we have encountered an interesting synthetic observation. We found that the application of a non-aqueous diazotization method on benzimidazole nucleosides with $t$-butyl nitrite has furnished an unexpected nitrated compound. These rather mild, non-acidic conditions make it an attractive and exploitable approach towards the selective functionalization of benzimidazole nucleosides. We are currently exploring the general use of this novel nitration method toward the synthesis of various structurally related heterocycles.

Acknowledgement: We thank Allison C. Westerman and Edward D. Kreske for performing the antiviral evaluation and cytotoxicity assays and Rae L. Herrst for the preparation of the manuscript. This research was supported by a Michigan Minority Merit Fellowship and federal funds from the Department of Health and Human Services research contract NO1-AI72641 and grant UO1-AI31718 as well as the National Institutes of Health Training Grant No. 5-T32-GM-07767.

\section{References and Notes}

1) A portion of this work was presented at the 199th American Chemical Society National Meeting, Division of Medicinal Chemistry, Abstract \#24, Boston, MA, April 22-27, 1990.

2) Townsend, L. B. and Wise, D. S., Parasitol. Today, 1990, 6, 107.

3) Tamm, I; Folkers, K.; Shunk, C. H.; and Horsfall, F. L., J. Exp. Med., 1954, 99, 227.

4) Cadogan, J. I. G.; Roy, D. A.; Martin, D. M., J. Chem. Soc. (C), 1966, 1249. Cadogan, J. I. G. and Molina, G. A., J. Chem. Soc., Perkin I, 1973, 541.

5) Nair, V.; Richardson, S. G., Tetrahedron Lett., 1979, 1181.

6) Nair, V.; Richardson, S. G., Synthesis, 1982, 670.

7) Nair, V.; Richardson, S. G., J. Org. Chem., 1980, 45, 3969.

8) Nair, V.; Young, D. A.; DeSiliva, R., J. Org. Chem., 1987, 52, 1344.

9) Robins, M. J.; Uznanski, B., Can. J. Chem., 1981, 59, 2608.

10) Townsend, L. B.; Revankar, G. R., Chem. Rev., 1970, 70, 389.

11) Revankar, G. R.; Townsend, L. B., J. Heterocyclic Chem., 1968, 5, 477.

12) Revankar, G. R.; Townsend, L. B., J. Heterocyclic Chem., 1968, 5, 615.

13) Compound 1 was synthesized in $51 \%$ yield by ribosylation of 2-amino-5,6-dichlorobenzimidazole (Horner, J. K. and Henry, D. W., J. Med. Chem., 1968, 11, 946) with bis(trimethylsilyl)acetamide (BSA), timethylsilyl trifluoromethanesulfonate (TMSOTf) and tetra-Q-acetyl- $\beta$-D-ribofuranose (TAR) in refluxing acetonitrile. mp: $88-89^{\circ} \mathrm{C}$. ${ }^{1} \mathrm{H}$ NMR $(\mathrm{CDCl})$ : $87.42(\mathrm{~s}, 1 \mathrm{H}), 7.27(\mathrm{~s}, 1 \mathrm{H}), 5.87\left(\mathrm{~d}, 1 \mathrm{H}, 1^{1}-\mathrm{H}, 6.83 \mathrm{~Hz}\right)$, $5.58\left(\mathrm{~s}, 2 \mathrm{H}, \mathrm{Ar}-\mathrm{NH}_{2}\right), 5.47\left(\mathrm{t}, 1 \mathrm{H}, 2^{\mathrm{t}}-\mathrm{H}\right), 5.37\left(\mathrm{dd}, 1 \mathrm{H}, 3^{\prime}-\mathrm{H}\right), 4.48\left(\mathrm{dm}, 2 \mathrm{H}, 5^{\prime}-\mathrm{H}\right), 4.35$ (m, $1 \mathrm{H}, 4^{\prime}-$ H), $2.17(\mathrm{~s}, 3 \mathrm{H}), 2.15(\mathrm{~s}, 3 \mathrm{H}), 1.99(\mathrm{~s}, 3 \mathrm{H}) .{ }_{13} \mathrm{C} \mathrm{NMR}\left(\mathrm{CDCl}_{3}\right): \delta 170.04,169.56,169.11,154.57$, $141.64,132.53,125.90,123.45,117.72,109.49,85.78,80.99,70.95,69.83,62.91,20.74,20.54$, 20.20. $\mathrm{MS}(\mathrm{FAB}+\mathrm{)}: \mathrm{m} / \mathrm{z} 460$. 
14) Compound 8: Yield from 1: $33 \% . \mathrm{mp}: 186-187^{\circ} \mathrm{C}$. IR (KBr): $1542 \mathrm{~cm}^{-1}$. 1H NMR (DMSO-d6): $\delta$ $10.05(\mathrm{~s}, 1 \mathrm{H}, \mathrm{N}-\mathrm{H}), 7.56(\mathrm{~s}, 1 \mathrm{H}, \mathrm{Ar}-\mathrm{H}), 5.96\left(\mathrm{~d}, 1 \mathrm{H}, 1^{\prime}-\mathrm{H}, 6.59 \mathrm{~Hz}\right), 5.65\left(\mathrm{t}, 1 \mathrm{H}, 2^{\prime}-\mathrm{H}\right), 5.46(\mathrm{dd}, 1 \mathrm{H}$, $\left.3^{\prime}-\mathrm{H}\right), 4.41\left(\mathrm{dm}, 2 \mathrm{H}, 5^{\prime}-\mathrm{H}\right), 4.35\left(\mathrm{~m}, 1 \mathrm{H}, 4^{\prime}-\mathrm{H}\right), 2.20(\mathrm{~s}, 3 \mathrm{H}), 2.15(\mathrm{~s}, 3 \mathrm{H}), 2.05(\mathrm{~s}, 3 \mathrm{H})$. ${ }^{13} \mathrm{C}$ NMR (DMSO-d 6 ): $\delta 170.37,169.84,169.74,152.70,131.11,128.63,127.93,125.07,120.53,114.90$, $84.85,80.13,70.37,69.94,63.14,20.89,20.49,20.34$. MS (EI with DCI probe): $m / 2506$.

15) Compound 10: mp: $235-236{ }^{\circ} \mathrm{C}$. ${ }^{1} \mathrm{H}$ NMR (DMSO-d 6$): 810.62(\mathrm{~s}, 1 \mathrm{H}, \mathrm{N}-\mathrm{H}), 7.15(\mathrm{~s}, 1 \mathrm{H}, \mathrm{Ar}-\mathrm{H})$, $5.59\left(\mathrm{~d}, 1 \mathrm{H}, 1^{*} \mathrm{H}, 7.37 \mathrm{~Hz}\right), 5.44\left(\mathrm{bs}, 2 \mathrm{H}, \mathrm{NH}_{2}, \mathrm{D}_{2} \mathrm{O}\right.$ exchangeable), $5.16\left(\mathrm{~d}, 1 \mathrm{H}, 2^{\prime}-\mathrm{OH}\right), 5.05(\mathrm{~m}, 2 \mathrm{H}$, $3^{\prime}-\mathrm{OH}^{\prime}$ and $\left.5^{\prime}-\mathrm{OH}\right), 4.43\left(\mathrm{q}, 1 \mathrm{H}, 2^{\prime}-\mathrm{H}\right), 4.04\left(\mathrm{~m}, 1 \mathrm{H}, 3^{\prime}-\mathrm{H}\right), 3.82\left(\mathrm{~m}, 1 \mathrm{H}, 4^{\prime}-\mathrm{H}\right), 3.58\left(\mathrm{~m}, 2 \mathrm{H}, 5^{\prime}-\mathrm{H}\right)$. ${ }^{13}$ C NMR (DMSO-d 6 ): $\delta 153.41,129.89,127.34,124.26,113.93,109.12,101.22,86.05,85.07$, 70.18, 69.71, 61.60. MS (EI with DCI probe): $\mathrm{m} / 2349$.

16) Compound 3: Isolated as a foam. ${ }^{1} \mathrm{H}$ NMR $\left(\mathrm{CDCl}_{3}\right): 87.81(\mathrm{~s}, 1 \mathrm{H}), 7.75(\mathrm{~s}, 1 \mathrm{H}), 6.07$ (d, 1H, 1'-H, $7.02 \mathrm{~Hz}), 5.43\left(\mathrm{~m}, 2 \mathrm{H}, 2^{\prime}-\mathrm{H}\right.$ and $\left.3^{\prime}-\mathrm{H}\right), 4.47\left(\mathrm{dm}, 2 \mathrm{H}, 5^{\prime}-\mathrm{H}\right), 4.35\left(\mathrm{~m}, 1 \mathrm{H}, 4^{\prime}-\mathrm{H}\right), 2.27(\mathrm{~s}, 3 \mathrm{H}), 2.14(\mathrm{~s}$, $3 \mathrm{H}), 2.01(\mathrm{~s}, 3 \mathrm{H})$. ${ }^{13} \mathrm{C} \mathrm{NMR}\left(\mathrm{CDCl}_{3}\right): \delta 170.25,169.50,168.95,145.43,132.27,127.68,120.72$, $112.53,103.82,90.03,80.61,70.89,69.31,62.79,20.89,20.39,20.07$. MS (FAB): m/z 445. MS(DCI with ammonia): $m / z$ 571. MS (EI $70 \mathrm{EV}): m / z 570$.

17) Compound 5 : 5,6 -Dichlorobenzimidazol-2-one $(3.0 \mathrm{~g}, 15 \mathrm{mmol})$ was dissolved in dry acetonitrile $(150 \mathrm{~mL})$ and stirred in an inert atmosphere at $60^{\circ} \mathrm{C}$. BSA $(4.03 \mathrm{~mL}, 16 \mathrm{mmol})$ was added and the mixture was stirred for $10 \mathrm{~min}$. 1,2,3,5-Tetra-Q-acetyl- $\beta$-D-ribofuranose $(4.7 \mathrm{~g}, 15 \mathrm{mmol})$ and TMSOTf $(3.14 \mathrm{~mL}, 16 \mathrm{mmol})$ were added to the clear solution and the mixture was allowed to stir at $60^{\circ} \mathrm{C}$ for $1 \mathrm{~h}$ and then for $16 \mathrm{~h}$ at room temperature. The mixture was concentrated under reduced pressure and separated on a silica gel column to yield $3.57 \mathrm{~g}(52.3 \%)$ of 5,6-dichloro-1-(2,3,5-tri-Q-acetyl- $\beta$-D-ribofuranosyl)benzimidazol-2-one. mp: $177-178^{\circ} \mathrm{C}$. ${ }^{1} \mathrm{H} \mathrm{NMR}\left(\mathrm{CDCl}_{3}\right): \delta 10.37(\mathrm{~s}, 1 \mathrm{H}), 7.33(\mathrm{~s}, 1 \mathrm{H}), 7.19(\mathrm{~s}, 1 \mathrm{H}), 5.97\left(\mathrm{~d}, 1 \mathrm{H}, 1^{\prime}-\mathrm{H}, 6.75\right.$ $\mathrm{Hz}), 5.73\left(\mathrm{t}, 1 \mathrm{H}, 2^{\prime}-\mathrm{H}\right), 5.49\left(\mathrm{dd}, 1 \mathrm{H}, 3^{\prime}-\mathrm{H}\right), 4.41\left(\mathrm{~m}, 3 \mathrm{H}, 4^{\prime}-\mathrm{H}^{\prime}\right.$ and $\left.5^{\prime}-\mathrm{H}\right), 2.21(\mathrm{~s}, 3 \mathrm{H}), 2.14(\mathrm{~s}, 3 \mathrm{H})$, $2.04(\mathrm{~s}, 3 \mathrm{H}) .{ }^{13} \mathrm{C} \mathrm{NMR}\left(\mathrm{CDCl}_{3}\right): \delta 170.51,169.68,169.58,154.64,127.59,127.36,126.38,125.31$, $111.61,111.34,84.48,79.67,70.16,69.96,63.14,20.92,20.53,20.37$. MS (EI with DCI probe): $\mathrm{m} / \mathrm{z}$ 460 .

18) Clark, R. L. and Pessolano, A. A., J. Am. Chem. Soc., 1958, 80, 1657. ${ }^{1}$ H NMR (DMSO-d 6 ): 87.07 $(\mathrm{s}, 2 \mathrm{H}), 10.93(\mathrm{~s}, 2 \mathrm{H}) .{ }^{13} \mathrm{C}$ NMR $\left(\mathrm{DMSO}-\mathrm{d}_{6}\right): \delta 109.74,122.39,129.84,155.22$.

19) Turk, S. R.; Shipman, C., Jr.; Nassiri, M. R.; Genzingler, G.; Krawczyk, S. H.; Townsend, L. B.; and Drach, J. C., Antimicrob. Agents Chemother., 1987, 31, 544.

20) Prichard, M. N.; Turk, S. R.; Coleman, L. A.; Engelhardt, S. L.; Shipman, C., Jr.; and Drach, J. C., J. Virol. Methods, 1990, 28, 101 . 